\title{
Tuberculosis the Big Mime
}

\section{S Benzerga*, C Michaux, E Calvo Lasso De Lavega and T Staub}

Infectious Diseases, CH de Luxembourg, Luxembourg

*Corresponding Author: S Benzerga, Infectious Diseases, CH de Luxembourg,

Luxembourg
Received: March 11, 2020

Published: April 17, 2020

(C) All rights are reserved by $\mathbf{S}$ Benzerga.

et al.

\section{Abstract}

Tuberculosis is a high prevalence disease in different part of world. Even though pulmonary presentation is the most frequent, let's not forget the extra-pulmonary one which is less frequent and which symptoms are not specific and can mime other diseases. Keywords: Tuberculosis; Inflammatory Bowel Disease (IBD)

\section{Introduction}

Mr N. 59 years old, of Vietnamese origin having stayed several months in Ukraine, is hospitalized for a deterioration of the general state with loss of 5 kilos in 1 month associated with painful perianal ulceration gradually 3 months ago. Note the absence of fever and any other symptomatology, digestive or respiratory.

\section{Observation}

Clinical examination notes a large ulcerated hemi-circumferential gluteal area left hyperalgesia (Figure 1) continuing inward with digital rectal examination. There is no peripheral lymphadenopathy or hepatosplenomegaly, auscultation cardiopulmonary is normal.

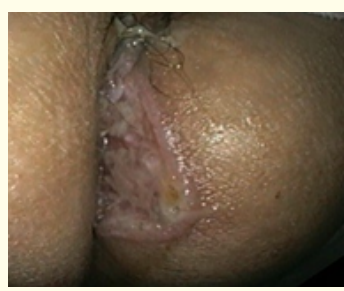

Figure

Biologically, there is a mild inflammatory syndrome with CRP to $8.6 \mathrm{mg} / \mathrm{L}$ and a $10300 / \mathrm{mm}^{3}$ hyperleukocytosis predominantly polynuclear neutrophils. Faecal calprotectin amounts to $791 \mathrm{ng} /$ $\mathrm{kg}$ (normal $<50-200 \mu \mathrm{g} / \mathrm{g}$ of stool). HIV serology is negative. The biopsy of the lesion shows a granulomatous inflammation and eliminates a tumour origin. Endoscopies digestive systems do not find any other associated lesion. Diagnosis of disease chronic inflammatory bowel disease (IBD) is strongly discussed.
Finally, the PCR of mycobacterium tuberculosis on biopsy returns positive, the diagnosis will be confirmed by a positive culture on liquid medium. To note also, a positive Gamma release assay Interferon. The chest scanner, performed in a second step, highlights calcified condensations apical, pulmonary involvement is confirmed by positive cultures.

A classic quadritherapy is started, the evolution is favourable with a decrease in the size of the ulceration and a resumption of 2 kilos to a month.

\section{Discussion}

Digestive tuberculosis is well described and represents $49 \%$ of tuberculosis extra-pulmonary [1], mainly in countries with high prevalence, a fortiori in immunocompromised patients. It most often affects the island region caecal in $44 \%$, the peritoneum or lymph nodes while the perianal localization is rare estimated at $3 \%$ [2]. Pulmonary involvement is associated in $20-25 \%$ of case [3]. Biopsy PCR is positive in $65 \%$ of cases while staining of Ziehl-Neelsen is not very profitable with $20 \%$ of positivity [3].

Faecal calprotectin is a biomarker whose increase indicates the existence of mucosal lesions of the digestive tract, it is not specific for IBD and does not does not dispense with the search for differential diagnoses.

\section{Conclusion}

Any atypical digestive impairment of a patient coming from an endemic area must evoke tuberculosis and have specific tests performed to avoid digestive complications sometimes severe.

\section{Bibliography}

1. Khan R., et al. "Diagnostic dilemma of abdominal tuberculosis in non-HIV patients: an ongoing challenge for physicians". World Journal of Gastroenterology 12.39 (2006): 6371-6375. 
2. Kentley J., et al. "Intestinal tuberculosis: a diagnostic challenge". Tropical Medicine and International Health 22.8 (2017): 994-999.

3. Bruce Wembulua Shinga., et al. "Intestinal tuberculosis revealed by acute bowel obstruction during paradoxical reaction to antituberculosis treatment in an immunocompetent patient: about a case and literature review". Pan African Medical Journal 32 (2019): 173.

Assets from publication with us

- Prompt Acknowledgement after receiving the article

- Thorough Double blinded peer review

- Rapid Publication

- Issue of Publication Certificate

- High visibility of your Published work

Website: https://www.actascientific.com/

Submit Article: https://www.actascientific.com/submission.php Email us: editor@actascientific.com

Contact us: +919182824667 